\title{
The Relationship Between Self Efficacy and Readiness for Change: The Mediator Roles of Employee Empowerment
}

\author{
Bagus Emsza P \\ baguspradhani@gmail.com \\ Anis Eliyana \\ Management Department Universitas Airlangga; anis-e@feb.unair.ac.id \\ Wiwik Istyarini \\ Economic Faculty Universitas Al Anwar; Wiwik.istyarini666@gmail.com
}

Doi:10.5901/mjss.2016.v7n3s1p201

\begin{abstract}
This study aimed to determine the effect of self-efficacy toward readiness for change, through employee empowerment of employees of PT Pos Indonesia (Persero) Surabaya. The variables used in this study are: Self-efficacy, employee empowerment and readiness for change. This study used a quantitative approach with survey method and supported by primary data from interviews and questionnaire. This study used primary data from 55 employees, where the data is retrieved by using a questionnaire distributed to permanent employees of PT Pos Indonesia (Persero) Surabaya. A data analysis technique that was used to answer the hypothesis in this study is the Partial Least Square (PLS). The results of this study demonstrated that there is significant influence on self-efficacy toward readiness for change and self-efficacy toward readiness for change through employee empowerment that is partial mediation.
\end{abstract}

Keywords: Employee, Self-Efficacy, Employee Empowerment, Readiness For Change

\section{Introduction}

Dealing with the rapid change in business environment, companies are encouraged to make changes in order to be able to grow and survive in the competitive business competition. Therefore it is necessary to have organizational changes within the organization itself, such as by increasing employees' self confidence in the organization so that they are ready to anticipate the changes that will be undertaken by the organization. The enhancement of readiness for change in companies or organizations can be done among others by empowering employees through the work flexibility to improve employees' confidence. So that they will be ready to face the changes that will be undertaken by the organization, in this case is PT Pos Indonesia persero) Surabaya. PT Pos Indonesia (persero) Surabaya is required not only to provide qualified public services but also to make changes in the organization. This study would focus on the assessment on the readiness for change from the individual perspective which is the employee as a member of organization in organizational change conducted by PT Pos Indonesia (persero) Surabaya. Therefore, the employees are able to carry out their work and responsible for their overall actions that they do (Filler: 2001; Pastor: 1996 ) in Eliyana (2014). Based on the above notion, then, this study are aimed 1)to measure the effect of self efficacy on readiness for change and 2) to find out the mediation role of employee empowerment toward self efficacy on readiness for change. Therefore the researcher would be proposed the research on "The influences of self efficacy on readiness for change through employee empowerment mediation in PT. Pos Indonesia (persero) Surabaya.

\section{Basic Theory and Hypothesis Development}

Bandura (1997) defines that self-efficacy is one of individual self- regulating abilities. Self efficacy refers to the perception of individual's ability to organize and implement actions to display certain skills. Cunningham (2002) defines that employees who have higher self efficacy towards change and have more contribution towards change intervention will ease the organization to do the change. The higher the self-confidence owned by the employees, the easier the 
employees accept the change undertaken by the organization. The employees who have high self-efficacy will easily to be given a briefing and easily to be empowered so that the change done by the organization will work effectively. The changes in the organization will have good impact either for the organization or for the person or individual in the organization because the changes can be accepted. In this study self-efficacy variable may act as a variable that can affect readiness for change of the employees through employee empowerment.

$\mathrm{H1}$ : Self efficacy has significant influence on the readiness for change on employees of PT. Pos Indonesia (persero) Surabaya. Assignment or empowerment is one of the factors that support a change that will be done by an organization. Bowen and Lawler in Margaret (1997) Empowerment has been described as a means to allow employees to make decisions and to be a person. The phenomenon in which people take responsibility for their own actions (Pastor, 1996). Employee empowerment can affect directly to the employees' readiness to change. According to Jones in Margaret (1997) defines that the key of organizational change based on the individual not on the information technology. Concerning that key of organizational change is an individual person therefore, before making changes the organization should providing support for the employee in order to be able to anticipate the changes that will be done by the organization. If the self-efficacy of the employees has been empowered, it will certainly prepare the employee to deal with any changes in the organization. It is because they will have the same vision and mission with the organization to become better organization.

$\mathrm{H} 2$ : Self efficacy has indirect and significant influence on the readiness for change with employee empowerment as mediating variable on employees of PT. Pos Indonesia (persero) Surabaya.

Framework thinking in this study can be seen as follow:

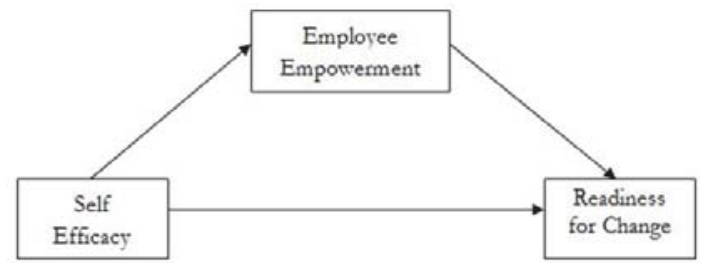

Picture 2.1. Framework Thinking

\section{Research Methods}

This study used quantitative approach with population research type since all research object were observed. However, due to the research object or the sample size was less than hundred people therefore this study would use Partial Least Square (PLS) as data analysis technique. This study was designed to explain the effects between variables or relationship influence (causality) between variables through hypothesis testing or through confirming the relationship influence between variables or construct. Moreover, this study can also be regarded as an explanatory research which means this research aimed to prove whether there is a relationship between one variable to another variable or how one variable affect other variables studied.

Primary data obtained from the questionnaire result in which it included the studied variables: self-efficacy, employee empowerment, readiness for change. The questionnaires were distributed to the employees of PT. Pos Indonesia (persero) Surabaya.

There were four variables studied which are self-efficacy $(X)$, employee empowerment $(Z)$, readiness for change $(\mathrm{Y})$, and performance $(\mathrm{Y})$. Mechanical Partial Least Square (PLS) was used to analyze the causal relationship between self-efficacy, employee empowerment and readiness for change based on the proposed hypothesis. PLS has two stages of analysis which are the inner evaluation model (to test the construct validity and reliability) and outer evaluation model (to test until to what extent the causal relationship between variables in the study)

\section{Result and Discussion}

\subsection{Description of Respondent Response}

The respondent's response description would explain the respondents' response about self-efficacy $(X)$, employee 
empowerment $(Z)$, and readiness for change $(Y)$. Respondent's response description was carried out by calculating the average (mean) respondent's response to each questions and to the overall. To categorize the average of respondents' response, it was used class interval which was sought with the following formula:

Class interval $=\frac{\text { The highest score }- \text { the lowest score }}{\text { The number of classes }}=\frac{5-1}{5}=0.8$

With the class interval of 0.8 , then the criteria of respondents' response was arranged, as presented in the table below:

Table 4.1. Criteria of the average respondents' response

\begin{tabular}{|c|c|c|c|c|c|}
\hline \multirow{2}{*}{ Variabel } & \multicolumn{5}{|c|}{ Interval Scale Rating } \\
\hline & $1,00-1,80$ & $1,81-2,60$ & $2,61-3,40$ & $3,41-4,20$ & $4,21-5,00$ \\
\hline Self-Efficacy $(X)$ & \multirow[b]{2}{*}{ Very Low } & \multirow[b]{2}{*}{ Low } & & & \\
\hline $\begin{array}{l}\text { Employee Empowerment }(\mathrm{Z}) \\
\text { Readiness For Change }(\mathrm{Y})\end{array}$ & & & & & \\
\hline
\end{tabular}

Source: Calculating result

\subsubsection{The description of the response on Self efficacy variable}

Based on the description of response table above, it can be concluded that the average response from the respondents to the variable Self Efficacy is at 4.09 which is included in the high category. It means that of permanent employees of PT Pos Indonesia have high self-confidence so that they believe that they can carry out his work by previously understand the job at the time the change occurred. It was proved by the indicator (X3) with average value of 4.16 . Whereas, the lowest level of self-efficacy that was perceived by the employee was related to the implementation of the changes made by PT Pos Indonesia (persero) Surabaya (X6). Although still included in the high category with an average value of 4.00, the employee assumed that the implementation of changes that would be done by PT. Pos Indonesia (persero) Surabaya was not fully effective even though the average of the overall employee could implement those changes.

\subsubsection{The description of the response on employee empowerment variable}

Based on the description of response table above, it can be concluded that the average response from the respondents to the variable employee empowerment is at 4.22 which is included in the extremely high category. It means that the permanent employees of PT. Pos Indonesia (persero) Surabaya already feel that their current job is very meaningful for them. It was proved by the indicator (Z1) with the average value of 4.27. Whereas the lowest level of employee empowerment that was perceived by the employee was related to decision making or the flexibility in completing their work (Z4) with the average value of 4.11. Although it still had been categorized as high but some employees still think that they cannot make decisions freely when they are given a certain job.

\subsubsection{The description of the response on readiness for change variable}

Based on the description of response table above, it can be concluded that the average response from the respondents to the variable readiness for change is at 4.25 which is included in the category of extremely high. It means that the permanent employee of PT. Pos Indonesia (persero) Surabaya already feel that they are always prepare for every changes conducted by PT Pos Indonesia (persero) Surabaya and do the best for their work. It was proved by the indicator (RCF5) with average value of 4.58 . Whereas the lowest level of readiness for change that was perceived by the employees was related to their direct involvement at the time PT Pos Indonesia (persero) Surabaya made changes. It can be seen in the indicator (RCF1). Although it was included in high category, some employee felt that they may not participate or involve directly in giving an appreciation when PT Pos Indonesia (persero) Surabaya made changes.

\subsection{Outer Model Evaluation (Validity and Reliability)}

PLS technique recognizes two types of validity: the convergent validity and discriminant validity. In the first stage of testing, there were still some items that did not comply with convergent validity provision with outer loading value more 
than 0.5 . Therefore those items that did not meet this condition should be reduced until it generate a suitable model as follow.

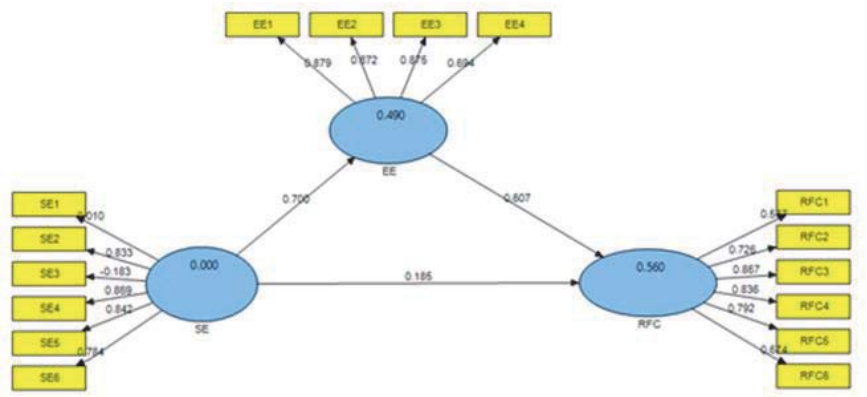

Picture 1.1. Outer Model

Source: PLS Data Running.

Meanwhile, the discriminant validity was done by comparing the cross loading of each variables in question to other variables in the model. If the cross loading value in one variable is greater than the other variables, the variables have good discriminant validity. Based on test results, it was known that the variables comply with discriminant validity. Final evaluation on the outer model is a composite reliability. Composite reliability tests reliability value of the indicators at a construct. A variable is said to meet the composite reliability if it has composite reliability value $>0.7$. Composite reliability value for self-efficacy, employee empowerment, and readiness for change, each is $0.900350,0.885682$, and 0.900448 . Based on this value, it can be concluded that those variables have complied with the reliability value.

\subsection{Inner Model Evaluation}

R-Square Value

Table 4.12. Average Result Of $\mathrm{R}^{2}$ Square

\begin{tabular}{|l|c|}
\hline Research Variable & $R$ Square \\
\hline Self Efficacy (SE) & \\
\hline Readiness for Change (RFC) & 0,560556 \\
\hline Employee Empowerment (EE) & 0,490444 \\
\hline Rata-rata $\mathbf{R}^{2}$ & 0,525500 \\
\hline
\end{tabular}

Source: Adapted from output SmartPLS 2014

Based on the calculations, the average value of communalities is at $.0,652033$ and the average value of R2 is at 0.525500 so that the $\mathrm{GoF}$ value is $\mathrm{GoF}=\sqrt{ }(0.652033 \times 0.525500)=0.58761(\mathrm{GoF}$ large $)$. From this result it can be concluded that the performance of measurement model (outer model) and structural model (inner model) has a great GoF value which is at 0.58761 (above 0.36 ). This indicated that the combined performance of the measurement model and the structural model is great.

\subsection{Hypothesis Testing}

The hypothesis could be accepted if the value of $t$-test (t-statistic) $>t$-table on the error rate e (a) of $5 \%$ is 1.96 . Here is the path coefficient value (original sample estimate) and the value of the $t(t$-statistic) on the inner workings of the model 
Tabel 4.13. Hasil Nilai Koefisien Path dan t-statistic

\begin{tabular}{|l|c|c|}
\hline Hipotesis & original sample & T-Statistic \\
\hline Self-efficacy-readiness for change & 0.617472 & 2.251 \\
\hline Self-efficacy-readiness for change (with employee empowerment mediation) & 0.184712 & 6.61 \\
\hline
\end{tabular}

Source: Calculating result.

From the table above, the structural model can be composed to prove the hypothesis of the study as follows:

The effect of self-efficacy towards readiness for change

The test result on the influence of self-efficacy toward readiness for change has statistical value of $2.251>1.96$. It means that self-efficacy has significant influence toward readiness for change. Therefore the first hypothesis was accepted. This result is in accordance with Holt (2008) that self-efficacy significantly affect readiness for change

The effect of self-efficacy towards readiness for change with employee empowerment mediation.

The employees who already feel empowered will have a sense of readiness including a sense of preparedness in dealing with the change. This can be seen from the relationship between variables $(Z)$ and $(Y)$ which were positively related to the value and t-statistic of $8.412>1.96$.

Based on these result it can be seen that the employee empowerment had positive influence on the readiness for change. This also means that the employee empowerment can give employees sense of preparedness in facing the challenges, including the challenges in the process of change. The Influence of Self-efficacy $(X)$ on readiness for change $(Y)$ without employee empowerment $(Z)$ in the model shows the t statistic value of $2.251>1.96$, so that it had significant effect. When employee empowerment mediates self-efficacy $(X)$ towards readiness for change $(Y)$ in the model, it showed the t-statistic value of $6.61>1.96$ which means that self-efficacy took effect on readiness for change, mediated by employee empowerment. Therefore the second hypothesis was accepted.

\section{Conclusion}

Based on the result of this study, it can be concluded that the high self efficacy influenced the behaviour of readiness for change. Based on the conclusion of the result and discussion above, it can sum up that the employees of PT. Pos Indonesia (persero) Surabaya had high self efficacy therefore it also affecting their readiness for change. This study aimed to test that self efficacy take effect on readiness for change through employee empowerment. Based on data processing result it can be concluded that the employee empowerment mediated the influence of self efficacy towards readiness for change on employees of PT. Pos Indonesia (persero) Surabaya. Moreover, the effect of mediation that produced was characterized as partial. In conclusion, some suggestions were given to the PT. Pos Indonesia (persero) Surabaya as follows:

\section{Suggestion}

1. PT Pos Indonesia (Persero) Surabaya should retain more of training to develop the knowledge and the ability to learn something to improve the employees' self efficacy. Even though the test showed that the PT PoS Indoneasia's employees have high self efficacy, however it would be better that PT Pos Indonesia (persero) Surabaya could be able to develop the employees self confidence so they can continue to empower the employees and ready to deal with all kinds of changes.

2. PT. Pos Indonesia (persero) Surabaya should maintain the effort to support the employees to feel that their work has meaning for them. Even though it included in high category, by maintaining their efforts, PT Pos Indonesia (persero) Surabaya can improve and evaluate their employees' self efficacy development. Therefore the employees are ready to face the chanegs implemented by PT. Pos Indonesia (persero) Surabaya.

3. PT. Pos Indonesia (persero) Surabaya should maintain employee empowerment to improve their employees' self efficacy so that they will be ready to carry out all kinds of work challenges including changes in the organization. By maintaining employee empowerment in their organization, the management of PT. PoS Indonesia (persero) Surabaya can evaluate how much the employees' self efficacy in order to be ready to deal with changes. 


\section{References}

Armenakis. A, A. Harris, S, G.. \& Mossholder, K. W, (1993). Creating readiness for organizational change. Human Relations, 46, 681703.

Bandura, A. (1986). Social foundation of tought and action: A social cognitive theory. New Jersey: Prentice-Hall,Inc.

Baron, R. M and Kenny, D. A., (1986.) The Moderator-Mediator Variable Distinction in Social Psychological Research: Conceptual, Strategic, and Statistical Considerations. Journal of Personality and Social Psychology. Vol. 51, No. 6, 1173-1182. American Psychological Association, Inc

Bowen, D.E. and Lawler, E.E. (1992), "The empowermentof service workers: what, why, howand when", Sloan Management Review, Vol. 33 No. 3, pp. 31-9.

Conger, J.A., Kanungo, R.N. (1988). "The empowerment process: integrating theory and practice". Academy of Management Review. 13:3:471-82.

Charles E. Cunningham et al. (2002). Readiness for organizational change: A longitudinal study of workplace, psychological and behavioral correlates. Journal of Occupational and Organizational Psychology Vol. 75, 377-392. McMaster University, Hamilton, Ontario, Canada.

Eliyana, Anis, (2014), "Perubahan Organisasi: Meta Analisis Identifikasi Pemberdayaan Karyawan PT. Pos Indonesia (persero)", Tim Riset Fakulta Ekonomi dan Bisnis Universitas Airlangga.

Erstrad, Margaret. 1997. Empowerment and Change, International Journal of Contemporary Hospitality Management, 9/7 (1997) pp. 325 -333 , MCB University Press.

Fadzilah, Ari. (2006). Analisis Pengaruh Pemberdayaan Karyawan Dan Self Of Efficacy Terhadap Kinerja Karyawan Bagian Penjualan (Studi Kasus PadaPt. Sinar Sosro Wilayah Pemasaran Semarang. Jurnal Studi Manajemen \& Organisasi Volume 3, No 1, Januari, Tahun 2006, Hal 13

Faryal Siddiqui .2011. Impact of Employee's Willingness on Organizational Change Journal of Economics and Sustainable Development ISSN 2222-1700 (Paper) ISSN 2222-2855 (Online) Vol.2, No.4. The Islamia University of Bahawalpur, Punjab, Pakistan.

Frazier, Patricia A. et al. 2004. Testing Moderator and Mediator Effects in Counseling Psychology. Vol. 51. No. 1.

Grau, R., Marisa S., Jose M. P. (2001). Moderator Effect of Self Efficacy on Occupational Stress. Psychology in Spain, vol.5 no.1, pp 6374.

Ghozali, Imam. 2005. Applikasi Analisis Multivariate dengan Program SPSS. Edisi Kedua. Semarang: Penerbit Universitas Diponegoro. Ghozali, Imam. 2008. Model Persamaan Struktural Konsep dan Aplikasi dengan Program Amos 16. Semarang: Badan Penerbit UNDIP. Heslin, P. A. (1999). Boosting empowerment by developing self-efficacy. Asia Pacific Journal of Human Resources, 37, 52-64 37, 52-64

Holt, Daniel., Armenakis, Field, S., \& Harris, G.(2007). Readiness for organizational change the systematic development of a scale. The journal of applied behavioral science, Vol. 43 No. 2, 232-255.

Jiang, J., Klein, G., \& Carr, C. (2002). Measuring information system service quality: SERVQUAL from the other side. MIS Quarterly, 26(2), 145-166

Ken Blancard, 2002. Empowerment (Take More Than a Minute), Amara Books.

Logan, L., Harley, W.B., Pastor, J., Wing, L.S.,Glasman, N., Hanson, L., Collins, D., Cleary, B.A., Miller, J. and Hegedahl, P. (1996), "Observations on the state of empowerment in today's organization", Empowerment in Organizations, Vol. 4 No. 1, pp. 6-11.

Madsen, SR (2003), "Wellness in the workplace: preparing employees for change", Organization Development Journal, Vol. 21, No. 1, pp. 46-55.

Martin S.Hagger.2001. The influence of self-efficacy and past behavior on the physical activity intentions of young people. Journal of Sports Sciences, Vol, 19, 711-725. University of Sheffield.

Patrick Briône and Chris Nicholson. 2012. Employee empowerment: towards greater workplace democracy.

Penelope Ann Gardiner (1999).Organization Theory to The Management To Change With reference to the Engineering Sector Human Resource Studies Group University of Plymouth Business School.

Spreitzer, G.M. (1995), Psychological empowerment in the workplace: dimensions, measurement, and validation, Academy of Management Journal, Vol. 38 No. 5, pp. 1442-65. 